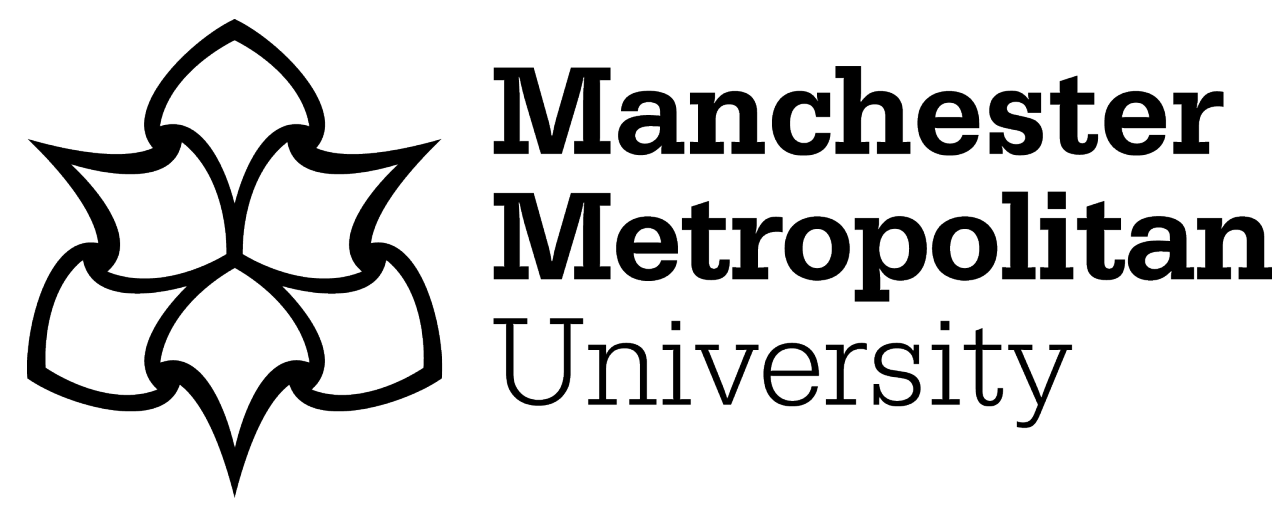

Djabarouti, Johnathan ORCID logoORCID: https://orcid.org/0000-00021326-7199 (2021) Stories of feelings and things: intangible heritage from within the built heritage paradigm in the UK. International Journal of Heritage Studies, 27 (4). pp. 391-406. ISSN 1352-7258

Downloaded from: https://e-space.mmu.ac.uk/628565/

Version: Accepted Version

Publisher: Informa UK Limited

DOI: https://doi.org/10.1080/13527258.2020.1798271

Please cite the published version 


\title{
Stories of feelings and things: intangible heritage from within the built heritage paradigm in the UK
}

\author{
The changing nature of heritage over recent decades has stimulated a focus on \\ intangible heritage - the understanding of which specifically from within the UK \\ built heritage paradigm remains inconclusive. This is problematic when \\ considering developments in policy and practice that demonstrate a steady \\ dismantling of a material focus. To gain sector-specific insight into how the \\ intangible heritage of buildings is conceptualised, a series of 16 semi-structured \\ interviews were conducted with built heritage professionals. Data was collated \\ into eight themes (stories; history; events; memory; use; discord; \\ craft; emotion) and an explanatory model developed, revealing the understanding \\ of intangible heritage as a collection of 'narratives' that contribute towards an \\ overarching building 'story'. Both 'buildings' and 'people' were acknowledged \\ as co-authors of this story; however, professionals did not acknowledge their own \\ role within the storytelling process. This downplays their role as curator of \\ heritage, as well as their personal experiences that inevitably shape the \\ storytelling process. Findings suggest built heritage practice should be \\ reconceptualised as a storytelling activity. This will offer greater opportunities \\ for intangible heritage to be consolidated within the built heritage paradigm, by \\ encouraging professionals to see themselves as translators of intangible heritage \\ as well as custodians of physical heritage.
}

Keywords: built heritage, intangible heritage, building conservation, heritage management, heritage assessment, heritage policy

\section{Introduction}

Heritage is increasingly understood as an intangible concept in both policy and practice (Smith 2006, 3; Smith and Akagawa 2009, 6; Pocock, Collett, and Baulch 2015, 964; Pétursdóttir 2013, 31; Vecco 2010, 323). This represents a major turning point in how society deals with cultural assets, and is considered to be part of the postmodern turn in 
heritage studies (Fairchild Ruggles and Silverman 2010; Muñoz Viñas 2002; Walter 2014). Formalised conceptions of the intangible heritage domain have been stimulated by the UNESCO (2003) 'Convention for the Safeguarding of the Intangible Cultural Heritage'. This convention charts the following shifts in understanding: static to dynamic interpretations of authenticity (Labadi 2013, 117); expert to community processes (Blake 2009, 45; Lenzerini 2011, 111); fixed interpretations to the acknowledgement of 'multiple temporal affiliations' (Dolff-Bonekämper and Blower 2012, 276); objective to subjective perspectives (Lenzerini 2011, 108); and global to local interests (Blake 2014, 46).

For built heritage professionals, these shifts challenge traditional educational and training objectives (Wain 2014, 54), which puts ephemeral notions of heritage out of step with prevailing professional views (Smith 2006, 2). The legislation that underpins these views has a history of promoting heritage as a series of constrained categories exclusively devised for material sites (DeSilvey 2017, 81), which places intangible heritage largely outside the scope of built heritage practice.

Yet as this paper will explore, there is a rising influence of an intangible conception of heritage within the built heritage sector, which implies a need to understand how those who work with historic buildings situate themselves within contemporary dialogues concerning the foregrounding of immaterial manifestations of culture. A series of 16 semi-structured interviews with built heritage professionals explores the following research questions: how do those who are tasked with assessing the significance of physical heritage define, perceive and understand intangible heritage? How do they accommodate a conception of intangible heritage within their role? Indeed, if they believe they consider intangible heritage, what exactly is it from 
their standpoint? And lastly, can a sector-specific definition or model be generated that elucidates their understanding(s) in relation to the existing literature on intangible heritage?

\section{Tangible heritage in the UK}

\section{'Anxieties about impermanence'}

The societal view of historic buildings as finite and fragile is a critical concept that underpins the UK emphasis on physical heritage sites and their conservation.

Holtorfand and Högberg $(2015,513)$ suggest this view may relate to “... a strong human desire to obtain a sense of purpose by caring for something profound...”. Lowenthal $(2015,352)$ states it may relate to the Western understanding of time as linear and unrepeatable, as it is through the passing of time that the majority of things deteriorate, grow old and disappear. It may also have a connection with the inherent mortality of human existence, with both Glendinning $(2013,17)$ and DeSilvey $(2017,158)$ noting the parallel between the decay of buildings and the vulnerability of human life. If, as Riegl $(2006,73)$ [originally 1903] states, we recognise ourselves in buildings, then it is likely we will impose our own living state on them and see them as 'living entities' that possess a 'social life' (DeSilvey 2017, 167; Walter 2014, 644).

It is this 'anxiety about impermanence' that has underpinned Western conservation practices to date (DeSilvey 2017, 166), which makes sense when considering the origin of the conservation movement itself emerged from the ‘existential reflection' of antiquarianism (Kobialka 2014, 358-59; Delafons 1997, 9).

Antiquarianism was broadened during the destructive Industrial Revolution in England 
(Glendinning 2013, 41) to include not just historic objects but also historic buildings (H. Silverman 2015, 71). Consequently, modes of building conservation emerged from the 'antiquarian approach' (Mydland and Grahn 2012), eventually manifesting as nineteenth century preservationist ideals centred around material authenticity, permanence, continuity and inherent value (de la Torre 2013; Jones 2017; Yarrow 2018; Smith and Waterton 2009). Ergo, building conservation practice is generally associated with the prevention of decay (Feilden 2003, 3), which encourages the process of changing (conserving or adapting) built heritage to be led by the material site and the values extracted directly from it (Pocock, Collett, and Baulch 2015, 962) - the quintessential point of departure for contemporary built heritage practice in the UK.

\section{'Conservation-planning assemblage'}

A focus on material sites in the UK positions heritage firmly within the confines of the planning system (Glendinning 2013, 285), creating a legal emphasis on physical heritage. Pendlebury $(2013,709)$ refers to this as the 'conservation-planning assemblage', which is designed to value and make decisions from the perspective of land-use planning (McClelland et al. 2013, 583). This assemblage reinforces an emphasis on physical sites, which the planning system is specifically calibrated to control (including the heritage listing system itself). The characteristics of this assemblage are convenient for built heritage professionals for a number of reasons: 1) the physical building fabric gives values a tangible, recognisable quality, allowing them to be clearly demarcated (Kearney 2009, 201); 2) it affords a static interpretation of buildings being most valued when in their original form (Tait and While 2009, 734); and 3) perceiving value as an inherent quality of a historic building means any 
assessment of this value will (at least in theoretical terms) yield the same results, regardless of who is assessing it. These characteristics are contra the aforementioned shifts in understanding that characterise an intangible conception of heritage.

Whilst the formalisation of intangible heritage in policy is heavily applicable to non-Western indigenous communities (Marrie 2009, 169; UNESCO 2003, 1), it can also be applied to Western communities, societies and their cultural practices particularly in relation to the 'consumption' of heritage things (Delle and Levine 2011, 52-53). This is perhaps why in the UK - despite a deeply rooted preoccupation with physical heritage - a steady dismantling of both the conservation-planning assemblage and the anxieties that underpin it, is not only feasible, but can also be demonstrated in developments across policy and practice.

\section{Intangible heritage in the UK}

\section{Some developments in policy}

The National Planning Policy Framework (2019) (hereafter the NPPF) and The National Lottery Heritage Fund (2019) (hereafter the NLHF) are two documents that best exhibit a decline in material focus in policy and guidance. The NPPF was originally introduced in 2012 and supersedes a host of prescriptive guidance notes for built heritage professionals within Planning Policy Guidance 15 (1994) (hereafter PPG 15). PPG 15 was a guidance document of circa 100 pages, with a heavy focus on the physical fabric of buildings. Some examples of this include:

C.40 As a rule, windows in historic buildings should be repaired, or if beyond repair should be replaced 'like for like'. 
C.20 Parapets (solid or balustraded), pediments, parapeted or coped gables and saddlestones, eaves, cornices and moulded cappings are essential terminal features in the articulation of an elevation. If they have to be replaced, it should be in facsimile and in the same materials.

(Department of the Environment 1994)

By comparison, the NPPF (Chapter 16: Conserving and Enhancing the Historic Environment) has removed all prescriptive building-specific instruction, replacing it with a mere three and a half pages of guidance that emphasises the importance of community enjoyment, social and cultural benefits, and viable uses of heritage (Ministry of Housing Communities \& Local Government 2019, 54-55).

Similarly, the NLHF's more recent 'Strategic Funding Framework' (The National Lottery Heritage Fund 2019) not only makes explicit the importance of people/ communities within funding applications, but also defines a more inclusive understanding of heritage, as well as making explicit reference to intangible heritage in the UK:

Our understanding of the ways in which heritage might be considered at risk is broad. It includes. . intangible heritage and cultural practices that might be lost.

(The National Lottery Heritage Fund 2019, 16)

It also clarifies that there is no statutory agency responsible for intangible heritage in the UK (The National Lottery Heritage Fund 2019, 51), which explains the lack of UK funding for intangible heritage since 1994 (4\%) in comparison to the funding for historic buildings and monuments (37\%) (Historic England 2008, 13).

Historic England's 'Conservation Principles, Policies and Guidance' (2008) must also be noted alongside these documents. Whilst having long offered implicit 
recognition of intangible heritage under its heading 'communal value' ('symbolic', 'social', and 'spiritual') (Historic England 2008, 31), its position within the overarching 1990 Act means these values lack formal prominence and are often overlooked in practice (Jones 2017, 22; Chitty and Smith 2019, 284). Furthermore, a more recent 'Consultation Draft' of an updated Conservation Principles has removed 'communal value' as a category in its own right - instead shoehorning 'communal value' within 'historic interest' (Historic England 2017, 7). Unsurprisingly, the draft also now explicitly states that "[i]t does not directly address intangible heritage" (Historic England 2017, 1).

\section{Some developments in practice}

Reinterpretations of existing listed buildings and the listing of new buildings also demonstrates a broadening of approaches. There are many recent listing examples that appear to contradict the traditional Western perspectives on what a listed building is and why it should be listed. Petrol stations, bus shelters, huts and bike sheds all now formally represent the tangible heritage domain with their listed representatives ${ }^{1}$. For example, the Bletchley Park Huts in Milton Keynes were listed Grade II in 2005, and each described within their listing description as an ' ...undistinguished building architecturally' (Historic England 2005). Instead of concerns of an architectural or aesthetic nature they are instead listed for their past uses and atmosphere (Lake and Hutchings 2009, 94). Any attention given to their physical fabric is concerned with their 
use - a physical tribute to both the people who worked there and the codebreaking work undertaken (Monckton 2006, 294).

Other examples include the Wake Green Road Prefabs in Birmingham, listed Grade II in 1998. Whilst originally listed due to their historic associations with WWII and their physical rarity, a more recent conservation management plan prepared for Birmingham City Council in 2019 heavily acknowledges the collective memories of the people who lived in or around them, as well as the '...memories of those who didn't survive the war...' (Robson 2019, 40). It is subsequently becoming more common that prefabs such as these are celebrated as a testement to the 'ordinary', and celebrated primarily because of their intangible qualities. These qualities are often centred on 'communicative memory', a non-institutional 'informal generational memory' that is part of everyday processes and rituals (Assmann 2008). This scheme in particular has paved the way for further designations of a similar nature (Blanchet and Zhuravlyova 2018,84 ), increasing focus on everyday living memory within the heritage assessment process. This is all despite there being no formalised approaches established to accomplish this.

\section{Postmodern problems and affective things}

An emphasis on the intangible heritage domain has sought to destabilise the notion of intrinsic material authenticity (Smith and Campbell 2017, 29; Smith 2006, 5-6), which in turn counteracts historically positivist, objective and quasi-scientific approaches towards heritage and conservation (Jones and Yarrow 2013, 6; Walter 2014, 635; Hassard 2009, 278). These are key tenets that form part of what Olsen $(2010,3)$ describes as a "...dominant antimaterial conception of culture and society within the 
human and social sciences". Whilst this overarching antimaterial approach has encouraged a multiplicity of meanings through subjective and ever-changing perceptions (Dolff-Bonekämper and Blower 2012, 276; Kamel-Ahmed 2015, 73; Taylor $2015,75)$, for some it has only served to heighten the theoretical detachment between materials and meanings:
But where does it lead us to claim that all heritage is intangible, that there are no such things as heritage? . . where does it leave things, in heritage, to deny them their tangibility or 'thingness'? And where does it leave heritage to ignore things' role, or to assign them innocence, in the discourse and construction of heritage conceptions?

(Pétursdóttir 2013, 33)

Skrede and Hølleland $(2018,89)$ believe the rejection of 'thingness' in critical conceptions of heritage ignores the affecting presence that material 'things' can have, as well as serving to reinforce the 'nature-culture split' that is at the root of UNESCO guidance (Witcomb and Buckley 2013; Hill 2018).

In the UK, the theoretical tension between acknowledging subjective human accounts (intangible) and objective nonhuman material things (tangible) creates a series of complexities for built heritage practice. Firstly, there is the overarching 'conceptual confusion' highlighted by Smith and Campbell $(2017,39)$, which they evidence through professional use of the contradictory terms 'tangible value' and 'intangible value'. Secondly, the acknowledgment of a multiplicity of subjective viewpoints results in an inability to regulate 'significance' (Labadi 2013, 13). Walter $(2014,638)$ warns this new broadening of heritage could 'devolve into a sort of "heritage X-Factor'" and similarly Glendinning $(2013,425)$ highlights how subjectivity could support 'false recollection or 
simple fiction'. Thirdly, the broadening of meanings and values of heritage is at odds with the overarching Parliamentary Act that determines the remit of the built heritage professional to be the physical 'architectural' and 'historic' qualities of things (HM Government 1990, 1). And lastly, if the value of heritage things is a product of society and thus subject to change across time (Smith and Campbell 2017, 31), then listed buildings - with their slow-moving and resource-heavy transformations - struggle to keep up with constantly shifting value judgements.

\section{Summary}

If the built heritage sector is still unable to consolidate well-known postmodern heritage matters within its day-to-day practices, then unsurprisingly, it will be ill-equipped to grapple with more recent ideas developed at the frontier of heritage studies. Whilst there are implicit developments taking place within built heritage policy and practice that brings the sector in closer alignment to the UNESCO declarations and charters - these changes are mostly implicit, fairly ambiguous, and do not actually hold professionals accountable for safeguarding immaterial manifestations of culture. This creates a confusing landscape for built heritage practice, with little clarity offered in relation to what intangible heritage actually means within their specific remit. A lack of detailed empirical studies on this matter that engage with those on the frontline of built heritage assessment, conservation and management is no doubt part of this complex issue. This clarity can only be achieved through understanding how these individuals conceptualise heritage domains, feelings and things within their day-to-day activities. 


\section{Empirical research}

\section{Sample, data collection and analysis}

Sixteen semi-structured interviews with UK-based built heritage professionals were conducted in 2019. This method generated 'narrative accounts' that illuminated understandings of intangible heritage from within the 'social world' of built heritage practice (Miller and Glassner 2004, 137). In an attempt to reflect the interdisciplinary nature of the sector and avoid the restricted views from any one specific profession, a variety of professionals were approached; however, the final sample consisted of $50 \%$ architects - no doubt a partial consequence of the researcher's own profession within the sector (refer to Table 1).

Table 1 - Interviewee roles across the sample.

\begin{tabular}{lc}
\hline Heritage role & Number of interviewees \\
\hline Accredited conservation architect & 6 \\
\hline Architect (not conservation accredited) & 2 \\
\hline Historic building surveyor & 2 \\
\hline Heritage planner & 1 \\
\hline Heritage consultant & 3 \\
\hline Archaeologist & 1 \\
\hline Governmental heritage role & 1 \\
\hline Total participants & $\mathbf{1 6}$ \\
\hline
\end{tabular}

Interviews were structured around three thematic topics: 1) understanding intangible heritage (perception, definition, identification and meaning); 2) intangible heritage in policy; and 3) intangible heritage and community engagement. The responses given for the first topic are the primary concern of this paper (refer to Table 2 for interview questions). Interviews were transcribed and then analysed using 'thematic synthesis' within qualitative data analysis software. 
Table 2 - Extract from interview script for Topic 1, 'Understanding intangible heritage'.

\begin{tabular}{|c|c|}
\hline No. & Question \\
\hline 1 & Have you heard of intangible heritage? \\
\hline $1 \mathrm{a}$ & If yes, what do you believe it means? \\
\hline $1 \mathrm{~b}$ & If no, what do you think it may mean or refer to? \\
\hline 2 & $\begin{array}{l}\text { Do you think professionals within the built heritage sector in general are aware of intangible } \\
\text { heritage? }\end{array}$ \\
\hline 3 & What do you think the main difference is between tangible and intangible heritage \\
\hline 4 & $\begin{array}{l}\text { From your experience, is intangible heritage something that people within the built heritage } \\
\text { sector consider when working with listed buildings? }\end{array}$ \\
\hline $4 a$ & Do you think this approach is correct? \\
\hline $4 b$ & What do you think the approach should be? \\
\hline $4 \mathrm{c}$ & Are there any other changes you would make? \\
\hline 5 & $\begin{array}{l}\text { If the built heritage sector were to increase awareness and importance of intangible heritage } \\
\text { when working with listed buildings, how would this impact: }\end{array}$ \\
\hline $5 \mathrm{a}$ & Your role? \\
\hline $5 b$ & The built heritage sector in general? \\
\hline $5 \mathrm{c}$ & The conservation and/or adaptation of listed buildings? \\
\hline
\end{tabular}

\section{Results}

\section{Overview}

The thematic analysis revealed eight primary themes that built heritage professionals discussed when considering the intangible heritage of buildings. In order of repetition frequency, these were: stories; history; events; memory; building use; discord; building craft; and emotion ${ }^{2}$ (refer to Table 3). The results for each theme will be discussed in this order, followed by a detailed discussion that consolidates the findings. 
Table 3 - Eight key themes extracted from data analysis.

\begin{tabular}{lll}
\hline Order & $\begin{array}{l}\text { Coded } \\
\text { theme }\end{array}$ & Sample descriptor quote \\
\hline 1 & Stories & 'It's social thing that's linked to storytelling' \\
\hline 2 & History & 'The human history of a place' \\
\hline 3 & Events & 'It is an event that maybe happened there' \\
\hline 4 & Memory & 'You are playing with memories' \\
\hline 5 & Use & 'Can you put more importance on a specific use?' \\
\hline 7 & Discord & 'It is not always positive' \\
\hline 8 & Craft & 'A craft skill is an intangible thing' \\
\hline
\end{tabular}

\section{Stories: 'it's a social thing that's linked to storytelling'}

Intangible heritage was most commonly described as a story; relating either to a building, or to people associated with a building. Stories relating to a building fell into three categories: 1) stories of a building as a complete assemblage; 2) stories relating to the individual building materials; and 3) stories surrounding the methods of construction. Stories relating to people were generally associated with building users and 'the stories and recollections of what happened' (Interviewee 421225). For example, one interviewee stated intangible heritage "is linked to [the] working class... it's a social thing that's linked to storytelling' (Interviewee 901781).

Buildings and people were seen as co-narrators of these stories, with both contributing to the wider understandings of the conception of a building (its past) and 'how the building is changed to adapt to new uses and new technology' (its future) (Interviewee 870507). Overall, the context of a building story was often framed by interviewees as 'community centred' and relating to 'communal values', with its purpose to convey memory and emotion - not necessarily hard facts. As one interviewee explained about a current project: 
It is more about the community. . it's about the stories and recollections of what happened there. The building probably comes secondary to that - to those stories.

(Interviewee 421225)

\section{History: 'the human history of a place'}

The importance of history and 'historic significance' in relation to heritage assets was emphasised, with one interviewee explaining how it 'gives you a sense of what the building is about and what it means - even if that isn't entirely about what is still there' (Interviewee 334986). 'History' was used as a general term to capture ideas relating to both 'the use of buildings, how they function in the past' (Interviewee 552297) and 'the human history of a place' (Interviewee 870507). Two aspects of history were noted as being particularly important: 'historic personalities', such as 'a connection to Emeline Pankhurst' (Interviewee 421225) and 'historic milestones', like at Bletchley Park, where 'what happened there was so unbelievably important and changed the course of all our futures' (Interviewee 487627).

History was explicitly noted as having both a tangible and intangible quality manifesting as either a value that can impact meaning (e.g. historic value), or a physical record that can be interrogated (e.g. the building as a historic record). Unlike 'stories', 'history' was described as 'the objective fact about the place' (Interviewee 334986), and because of this was understood to have a different relationship with the 'memory' and ‘emotion' of a building.

\section{Events: 'it is an event that maybe happened there'}

Events were defined as activities and/ or traditions that have a connection with a building, and fell into cultural, political and communal/ social categories. Larger scale 
events with a collective social impact were described, like 'when the Sex Pistols played at the Free Trade Hall. . . that's definitely still intangible but culturally for Manchester it was so important' (Interviewee 901781); as well as smaller, personal scale events, such as the reflections of one interviewee regarding Rochdale Town Hall:

The intangible heritage there [Rochdale Town hall] might be completely different for different people. So, part of the heritage of that place for me is that my mum and dad got married there, and I played the violin there when I was little.

(Interviewee 509240)

Overall, interviewees described events as tied in with 'history' and 'memory' at varying scales - national, communal, personal - and acknowledged how they could be either positive or negative (e.g. the Peterloo Massacre was described as a negative event).

\section{Memory: 'you are playing with memories'}

Memories were believed to capture the spirit of a place, and professionals primarily talked about personal 'everyday' heritage narratives, comprised of 'social elements' and ‘personal experiences'. As one interviewee explained:

It may be that building or behind that building I met my girlfriend, or I smoked my first cigarette, or I listened to this really great story or something like that. Who knows? But buildings have got these layers of meaning for people and they can be very mundane but they are equally important.

(Interviewee 214600)

Memories therefore 'might not be [about] a historical figure, [rather] it's people in the real-life day that have an association with the project' (Interviewee 509240). 
However, the potentially infinite spectrum of these building memories made this a highly subjective theme:

Everyone has got a slightly different perspective on whether - you're a person who used to work in the building, a person who has walked past it every day, a person in another part of the country who has seen the building on television and sees it differently. Like the spirit of place is unique to every individual.

(Interviewee 477549)

In particular, it was felt that memories have the capacity to 'make something that traditionally might be regarded as insignificant, significant' (Interviewee 870507). However, interviewees noted that memories were not often considered by built heritage professionals when assessing significance. The elusive and ephemeral nature of memory is a likely reason for this, with the ability of memories to outlast the physical fabric adding conceptual confusion to the assessment process:

There is nothing left of Peterloo - St. Peters church and churchyard are gone. . . So where is the physical thing? It isn't there. But all of that non-physical heritage - the memories, the associations - are still there and still very strong.

(Interviewee 214600)

This perceived lack of integration and interaction with the memories of buildings was met with caution by some, with one interviewee stating 'you have to be careful when you are playing with buildings because you are playing with memories, you're playing with those associations' (Interviewee 214600).

\section{Use: 'can you put more importance on a specific use?'}

The previous uses of a building were highlighted as intangible contributions to the 
'history' and overall 'story' of the building:

The intangible sort of gives it a sense of place - what a building is; what it represents; how it used to be used; how it is used now; is that the right change of use.

(Interviewee 477549)

Building 'use' was considered to be comprised of physical evidence (the material site) and non-physical evidence (histories, stories, the lives of people who used the building). Interviewees noted how this particular theme required the correct balance of tangible and intangible qualities to uncover previous uses:

it is just sort of finding that balance. . . you can tell where a wall has been removed or an opening has been infilled. . you can also start to trace back how the building was used and the story of the building, so you have got the intangible and the tangible working together.

(Interviewee 477549)

Similar to 'memories', building use was perceived to be a subjective and variable quality, with one interviewee giving an example of an adapted church:

Can you put more importance on a specific use? And if you think about the people again, is there more importance to say church worshippers using a church, compared to an adaptive version of the church and it is now housing residents? In time, they will all have their own significance.

(Interviewee 550931)

As a result of this subjectivity, different building uses were described as being hard to prioritise. However, there was a general consensus that the original use/ function of a building was more likely to be its most important use. 


\section{Discord: 'it is not always positive'}

Intangible heritage was also discussed in relation to dissonant (dark/ contested/ negative) values/ significance:

Part of the intangible heritage is sometimes experiential, how people relate to the building, and it is not always positive.

(Interviewee 477549)

Interviewees felt there was inherent complexity in conserving any type of heritage with a negative association. Some examples of working with dissonant heritage included: slavery in Liverpool; the Pendle witch ghosts; the Moors Murders; Victorian mental asylums; graveyards; the Peterloo Massacre and holocaust memorials. Uncertainties regarding the interpretation and dissemination of dissonant heritage extended into concerns as to whether it should be conserved for future generations or not. Only one interviewee was optimistic regarding the potential value in conserving dissonant heritage:

Would you want to save it because it is the site of some atrocity, but then equally, do you not need to remember some of those atrocities to make sure things don't happen there after?

(Interviewee 487627)

The subjectivity of this theme was exemplified by one interviewee, who would 'buy a church and have a graveyard as [their] garden' but on the conversion of Victorian asylums into housing, stated:

That seems a bit weird to me, because to me the heritage there is pain. . I perceive that heritage - that intangible - but some other people don't, so I don't know? 
Regardless of this confusion, there was a sensitivity towards the need to develop a narrative that would be thoughtful, appealing and accommodating to everyone. As one interviewee neatly summarised:

Do you still promote it because at the end of the day you want to tell the story about how bad it was. . . but how do you go about it and how do you preserve it for future generations. . . you want to keep those memories going. And it is very difficult.

(Interviewee 647876)

\section{Craft: 'a craft skill is an intangible thing'}

Traditional craft skills were perceived as part of a building's intangible heritage primarily because of the relationship with technique, memory and thought:

It is skill isn't it, so a craft skill is an intangible thing. It is muscle memory and thought. It is intangible.

(Interviewee 373838)

Also noted was the overall connection between craft skills and human, social and political histories, with a particular emphasis being placed on those individuals who 'transmit' the skills. As one interviewee stated, 'it comes down to individuals who have learned it either through it being passed on or individuals who have taught it' (Interviewee 613193). Relationships of dependence and reliance were discussed, with interviewees noting the dependence of built heritage on craft skills and the reliance of craft skills on people. A reciprocal relationship was therefore perceived between buildings (tangible) and craft skills (intangible), with their union promoting a greater chance of inter-generational transmission and longevity of the heritage asset. 


\section{Emotion: 'it gets me in my heart'}

Intangible heritage was consistently associated with people's emotions towards a building. This was communicated using professional phrases such as 'personal value'; 'emotional value'; and 'emotional connection'. These concepts were generally understood to be autonomous to the building, having "nothing to do with the architecture or the building itself, the fabric, or the building techniques.' (Interviewee 421225). In this sense, interviewees felt emotional associations were all-embracing, non-scientific and highly subjective. Referring to a professional colleague, one interviewee offered a short but powerful anecdote that captures the complexity in representing the emotions of people within built heritage practice:

\footnotetext{
We went to a consultation event at another site in Wales, and they're quite passionate about their history which is just great. And there is a woman who came up to my colleague at the end of it, and he asked her, 'oh, did you find it interesting talking about significance, what do you think is significant about this place?' And she just said, "it gets me in my heart". You know, which is just brilliant, but at the same time he walked away and came back to me and he said, "how do we attribute that to the built fabric?"
}

(Interviewee 234834)

\section{Discussion}

\section{The building story}

From the perspective of the built heritage professionals who contributed to this study, the intangible heritage of buildings is understood as a complex landscape of building 'narratives' that collectively contribute towards an overarching building 'story' (see Figure 01 ). The building story was portrayed as a co-authorship between the building 
fabric (social production) and human epiphenomena (social construction), with various narratives extracted from both people and buildings.

Buildings were described as being able to tell their own unique stories and participate in the storytelling of heritage places (Ingold 2007, 14; similar to DeSilvey 2006, 318); as well as having the ability to affect and animate the world around them (Pétursdóttir 2013, 47; see Bennett 2010, xx). The historic building itself was therefore most commonly conceived as a manifestation of objective cultural memory (MüllerFunk 2003, 216), and best represented by the themes that were described as reliant on the physical building fabric - 'uses', 'events' and 'craft'. By comparison, themes that were described as subjective and often autonomous to the building fabric - 'memory', 'discord' and 'emotion' - were explained in relation to the interpretation of buildings and the creation of contemporary cultural memories (Müller-Funk 2003, 218). These themes were discussed across a variety of scales: positive-negative (e.g. 'discord'); personal-communal (e.g. 'memory'); fact-fiction (e.g. 'stories'); and historic-everyday (e.g. 'events'). 
AOM (Author's Original manuscript). This article has been accepted for publication in The International Journal of Heritage Studies, published by Taylor \& Francis. The final revised and published version is available at the following DOI:

https://doi.org/10.1080/13527258.2020.1798271

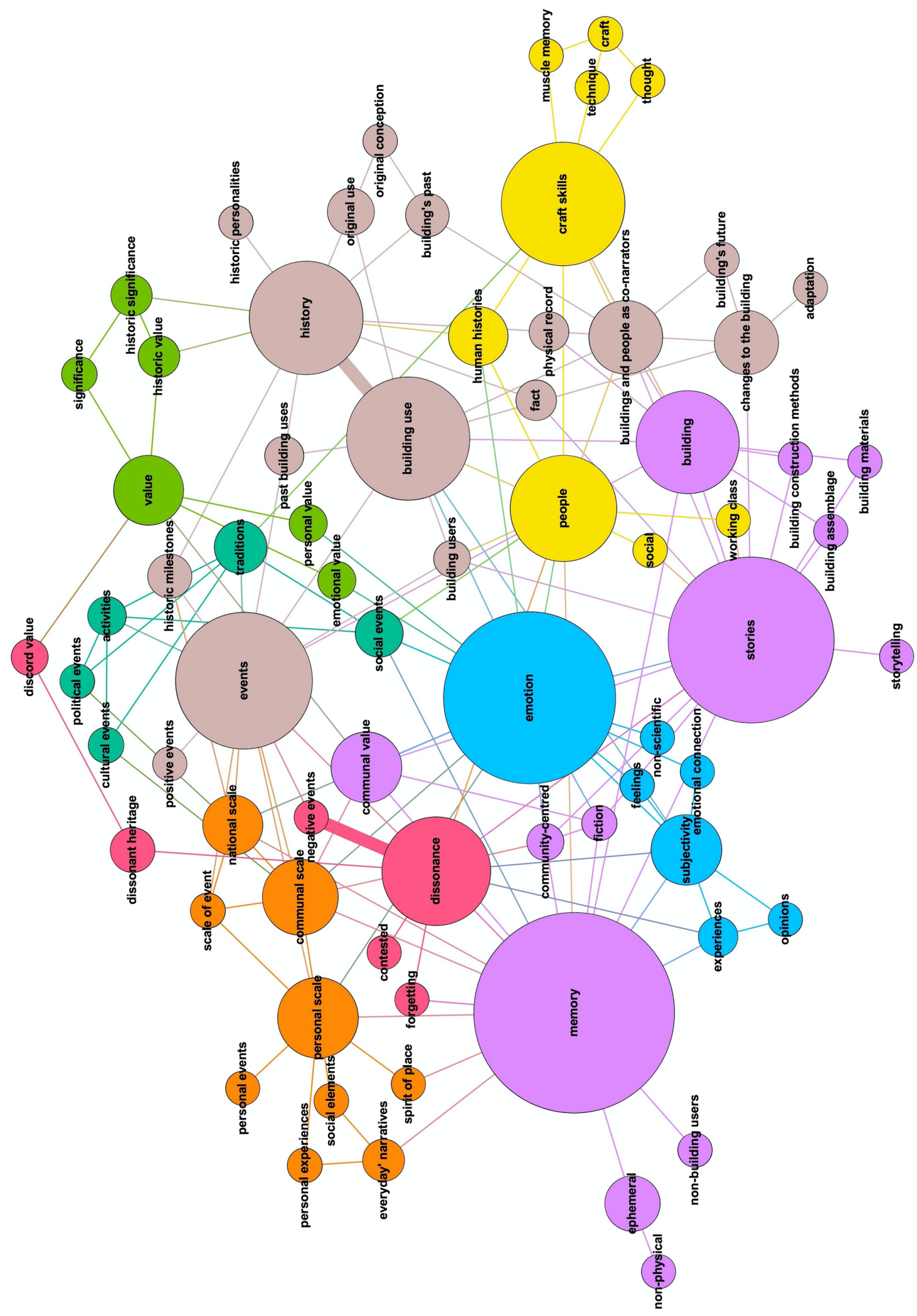

Figure 01 - The complex conceptual landscape of the building story. Author original image. 
By using stories to conceptualise intangible heritage within their material focussed sector, the interviewees were able to overcome the complexities of the perceived 'nature-culture split' (Hill 2018) and instead work towards a definition of heritage as an entanglement of feelings and things. Stories are particularly useful in this regard, as they are more than capable of expressing and organising a variety of conflicts and contradictions (Cameron 2012, 574) - enabling the interviewees to conceptualise the story as either the building (like Walter 2014, 645), or something other than building (similar to Pocock, Collett, and Baulch 2015, 966). The use of stories can therefore be understood as a reactionary method that was employed by the interviewees to overcome the perceived tangible-intangible duality; resonating with contemporary ontological developments in heritage studies that conceptualises heritage as assemblages and/or networks of various material and immaterial 'actors' (Harrison 2015; Hill 2018; Skrede and Hølleland 2018; Hamilakis 2017).

\section{The storyteller}

Stories are ultimately a reflection of the storytellers' personal and cultural perspectives (Whyte 2006, 155; see Stone 2019, 79). This makes storytelling a moving and affective act of interpretation - evoking personal experiences, expressions and emotions (Cameron 2012, 574). If stories are what built heritage professionals use to conceptualise the intangible heritage of buildings, then what of the storyteller? The professionals did not explore their own position in relation to the building story depicting instead a fairly passive role that objectively mediates between social and material worlds to uncover an impartial story. This perspective overlooks the significance of their role as curator of heritage values (see de la Torre 2013, 163); as 
well as their personal experiences that will inevitably shape the storytelling process (Cameron 2012, 575).

Conversely, if the role of the built heritage professional was more explicitly acknowledged as 'storyteller', it would not only be the historic building that assumes a mnemonic role (Stone 2019, 50), but also those responsible for conserving and adapting it (Rigney 2008, 347). The intangible heritage of buildings would accordingly be understood as a part-reflection of the professional's way of seeing the world entangling built heritage practice with the human and non-human narratives that the interviewees highlighted as inherent aspects of the building story (see Figure 02).

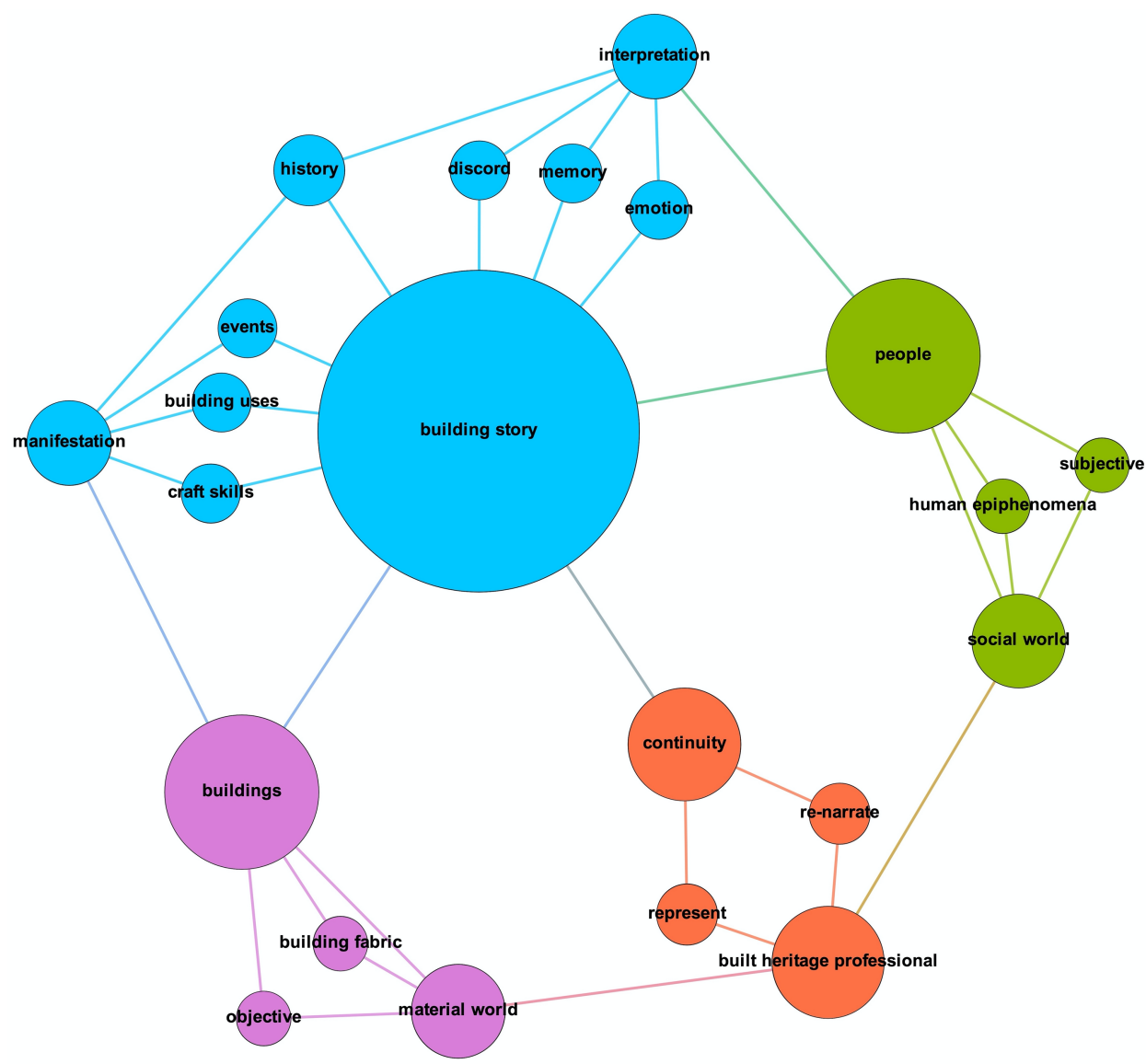

Figure 02 - The intangible heritage construct of the built heritage professional. A conceptual model derived from the primary research analysis. Author original image. 
The conceptualisation of intangible heritage within the built heritage paradigm therefore lies not so much in elucidating the relationship between tangible and intangible heritage; but in the ability for built heritage practice to re-evaluate its role as one that recreates, translates and transmits stories across generations (for example, see Scott 2008, 11; Plevoets and Cleempoel 2019, 16, 33; Stone 2019, 33). This not only requires support from sector-specific guidance and policy; but also, a self-awareness from professionals of their own personal involvement in narrative development including their own cultural and personal perspectives that inevitably form a part of this.

\section{By way of a conclusion}

An intangible conception of built heritage is a complex and somewhat paradoxical idea that must inevitably do battle with established sector-specific understandings and processes. Whilst built heritage practice is not yet formally structured to accommodate intangible conceptions of heritage, immaterial considerations are emergent and evident, which makes it essential that a more nuanced approach is developed in relation to its understanding from within the built heritage paradigm. By engaging with those who work with historic buildings, it was clear that whilst intangible heritage was hard to articulate, it was generally conceived as the building 'story' - a collaborative effort between buildings and people; material and social worlds. Within this model, the professional role as 'storyteller' was largely unacknowledged, despite the significant and persuasive curatorial role that they must adopt in the remembering/ forgetting of cultural memories and the spatial narration of the building story. Reconceptualising built heritage practice as a storytelling activity will offer greater opportunities for intangible heritage to be consolidated within the built heritage paradigm, by 
encouraging professionals to see themselves as translators of intangible heritage as well as custodians of physical heritage. An emphasis on 'storytelling' is therefore particularly relevant to the evolution of built heritage practice, evolving as it must to accommodate ever-changing conceptions of what heritage is and how it is understood.

\section{References}

Assmann, Jan. 2008. “Communicative and Cultural Memory.” In Cultural Memory Studies: An International and Interdisciplinary Handbook, edited by Astrid Erll and Ansgar Nünning, 109-18. Berlin: Walter de Gruyter.

Bennett, Jane. 2010. Vibrant Matter: A Political Ecology of Things. North Carolina: Duke University Press Books.

Blake, Janet. 2009. "The Implications of Community Involvement in 'Safeguarding.," In Intangible Heritage (Key Issues in Cultural Heritage), edited by Laurajane Smith and Natsuko Akagawa, 45-73. Oxon: Routledge.

Blake, Janet. 2014. “Seven Years of Implementing UNESCO’s 2003 Intangible Heritage Convention - Honeymoon Period or the Seven-Year Itch?” International Journal of Cultural Property 21 (3): 291-304. doi:https://doi.org/10.1017/S0940739114000113.

Blanchet, Elisabeth, and Sonia Zhuravlyova. 2018. Prefabs. Edited by Anne McDowall. Swindon: Historic England.

Cameron, Emilie. 2012. "New Geographies of Story and Storytelling." Progress in Human Geography 36 (5): 573-92. doi:https://doi.org/10.1177/0309132511435000.

Chitty, Gill, and Claire Smith. 2019. "Principles into Policy: Assessing the Impact of 
AOM (Author's Original manuscript). This article has been accepted for publication in The International Journal of Heritage Studies, published by Taylor \& Francis. The final revised and published version is available at the following DOI:

https://doi.org/10.1080/13527258.2020.1798271

Conservation Principles in Local Planning Policy." Historic Environment: Policy and Practice 10 (3-4): 282-99.

doi:https://doi.org/10.1080/17567505.2019.1652401.

Delafons, John. 1997. Politics and Preservation: A Policy History of the Built Heritage, 1882-1996. New York: Routledge.

de la Torre, Marta. 2013. "Values and Heritage Conservation." Heritage \& Society 6 (2): 155-66. doi:https://doi.org/10.1179/2159032X13Z.00000000011.

Delle, James A., and Mary Ann Levine. 2011. "Archaeology, Intangible Heritage, and the Negotiation of Urban Identity in Lancaster, Pennsylvania." Historical Archaeology 45 (1): 51-66. doi:https://doi.org/10.1007/BF03376820.

Department of the Environment. 1994. Planning Policy Guidance: Planning and the Historic Environment (PPG15).

DeSilvey, Caitlin. 2006. “Observed Decay: Telling Stories with Mutable Things.” Journal of Material Culture 11 (3): 318-38.

doi:https://doi.org/10.1177/1359183506068808.

DeSilvey, Caitlin. 2017. Curated Decay: Heritage Beyond Saving. Minneapolis: University of Minnesota Press.

Dolff-Bonekämper, Gabi, and Jonathan Blower. 2012. "National—Regional—Global? Old and New Models of Societal Heritage Constructions." Art In Translation 4 (3): 275-86. doi:https://doi.org/10.2752/175613112X13376070683234.

Feilden, B. 2003. Conservation of Historic Buildings. 3rd ed. London: Architectural Press.

Glendinning, M. 2013. The Conservation Movement: A History of Architectural Preservation. Oxon: Routledge. 
Hamilakis, Yannis. 2017. "Sensorial Assemblages: Affect, Memory and Temporality in Assemblage Thinking." Cambridge Archaeological Journal 27 (01): 169-82. doi:https://doi.org/10.1017/s0959774316000676.

Harrison, Rodney. 2015. "Heritage and Globalization.” In The Palgrave Handbook of Contemporary Heritage Research, edited by Emma Waterton and Steve Watson, 297-312. Hampshire: Palgrave Macmillon.

Hassard, Frank. 2009. "Intangible Heritage in the United Kingdom: The Dark Side of Enlightenment?” In Intangible Heritage (Key Issues in Cultural Heritage), edited by Laurajane Smith and Natsuko Akagawa, 270-88. Oxon: Routledge.

Hill, Matthew J. 2018. "World Heritage and the Ontological Turn: New Materialities and the Enactment of Collective Pasts." Anthropological Quarterly 91 (4): 11791202. doi:https://doi.org/10.1353/anq.2018.0062.

Historic England. 2005. "Historic England Listing: Hut 11 at Bletchley Park.” 2005. doi:https://perma.cc/KG75-YVLU [archived link].

Historic England. 2008. “Conservation Principles, Policies and Guidance.”

Historic England. 2017. “Conservation Principles for the Sustainable Management of the Historic Environment."

HM Government. 1990. Planning (Listed Buildings and Conservation Areas) Act.

Holtorfand, Cornelius, and Anders Högberg. 2015. "Contemporary Heritage and the Future." In The Palgrave Handbook of Contemporary Heritage Research, edited by Emma Waterton and Steve Watson, 509-23. Hampshire: Palgrave Macmillon. Ingold, Tim. 2007. “Materials against Materiality.” Archaeological Dialogues 14 (1): 1-16. doi:https://doi.org/10.1017/S1380203807002127.

Jones, Siân. 2017. "Wrestling with the Social Value of Heritage: Problems, Dilemmas 
AOM (Author's Original manuscript). This article has been accepted for publication in The International Journal of Heritage Studies, published by Taylor \& Francis. The final revised and published version is available at the following DOI:

https://doi.org/10.1080/13527258.2020.1798271

and Opportunities." Journal of Community Archaeology and Heritage 4 (1): 2137. doi:https://doi.org/10.1080/20518196.2016.1193996.

Jones, Siân, and Thomas Yarrow. 2013. "Crafting Authenticity: An Ethnography of Conservation Practice.” Journal of Material Culture 18 (1): 3-26. doi:https://doi.org/10.1177/1359183512474383.

Kamel-Ahmed, Ehab. 2015. "WHAT TO CONSERVE? Heritage, Memory, and Management of Meanings." International Journal of Architectural Research: ArchNet-IJAR 9 (1): 67-76. doi:https://doi.org/10.26687/archnet-ijar.v9i1.469. Kearney, Amanda. 2009. “Intangible Cultural Heritage: Global Awareness and Local Interest.” In Intangible Heritage (Key Issues in Cultural Heritage), edited by Laurajane Smith and Natsuko Akagawa, 209-25. Oxon: Routledge.

Kobialka, Dawid. 2014. "Let Heritage Die! The Ruins of Trams at Depot No. 5 in Wroclaw, Poland." Journal of Contemporary Archaeology 1 (2): 351-68. doi:https://doi.org/10.1558/jca.v1i2.18438

Labadi, Sophia. 2013. UNESCO, Cultural Heritage, and Outstanding Universal Value: Value-Based Analyses of the World Heritage and Intangible Cultural Heritage Conventions. Plymouth: Altamira Press.

Lake, Jeremy, and Fleur Hutchings. 2009. "The Enigma of Place: Reading the Values of Bletchley Park." In Europe's Deadly Century: Perspectives on 20th Century Conflict Heritage, edited by N. Forbes, R. Page, and G. Pérez, 87-97. Swindon: English Heritage.

Lenzerini, Federico. 2011. "Intangible Cultural Heritage: The Living Culture of Peoples.” European Journal of International Law 22 (1): 101-20. doi:https://doi.org/10.1093/ejil/chr006. 
Lowenthal, David. 2015. The Past Is a Foreign Country - Revisited. Cambridge:

Cambridge University Press.

Marrie, Henrietta. 2009. "The UNESCO Convention for the Safeguarding of the Intangible Cultural Heritage and the Protection and Maintenance of the Intangible Cultural Heritage of Indigenous Peoples.” In Intangible Heritage (Key Issues in Cultural Heritage), edited by Laurajane Smith and Natsuko Akagawa, 169-92. Oxon: Routledge.

McClelland, Andrew, Deborah Peel, Christa-Maria Hayes, and Ian Montgomery. 2013. “A Values-Based Approach to Heritage Planning: Raising Awareness of the Dark Side of Destruction and Conservation." Town Planning Review 84 (5): 583-603. doi:https://doi.org/10.3828/tpr.2013.31.

Miller, Jody, and Barry Glassner. 2004. 'Interviews: The 'inside' and the 'Outside': Finding Realities in Interviews." In Qualitative Research: Theory, Method and Practice, edited by David Silverman, 2nd ed. 125-39. London: Sage Publications. Ministry of Housing Communities \& Local Government. 2019. National Planning Policy Framework.

Monckton, Linda. 2006. "Bletchley Park, Buckinghamshire: The Architecture of the Government Code and Cypher School.” Post-Medieval Archaeology 40 (2): 291300. doi:https://doi.org/10.1179/174581306X160080.

Müller-Funk, Wolfgang. 2003. "On a Narratology of Cultural and Collective Memory.” JNT-Journal of Narrative Theory 33 (2): 207-27. doi:https://doi.org/10.1353/jnt.2011.0068

Muñoz Viñas, S. 2002. “Contemporary Theory of Conservation.” Studies in Conservation 47 (sup1): 25-34. 
AOM (Author's Original manuscript). This article has been accepted for publication in The International Journal of Heritage Studies, published by Taylor \& Francis. The final revised and published version is available at the following DOI:

https://doi.org/10.1080/13527258.2020.1798271

doi:https://doi.org/10.1179/sic.2002.47.Supplement-1.25

Mydland, Leidulf, and Wera Grahn. 2012. "Identifying Heritage Values in Local

Communities.” International Journal of Heritage Studies 18 (6): 564-87.

doi:https://doi.org/10.1080/13527258.2011.619554.

National Lottery Heritage Fund. 2019. “The National Lottery Heritage Fund Strategic

Funding Framework."

Olsen, Bjønar. 2010. In Defense of Things: Archaeology and the Ontology of Objects.

New York: Altamira Press.

Pendlebury, John. 2013. "Conservation Values, the Authorised Heritage Discourse and

the Conservation-Planning Assemblage." International Journal of Heritage Studies

19 (7): 709-27. doi:https://doi.org/10.1080/13527258.2012.700282.

Pétursdóttir, Thóra. 2013. "Concrete Matters: Ruins of Modernity and the Things Called

Heritage." Journal of Social Archaeology 13 (1): 31-53.

doi:https://doi.org/10.1177/1469605312456342.

Pocock, Celmara, David Collett, and Linda Baulch. 2015. “Assessing Stories before

Sites: Identifying the Tangible from the Intangible.” International Journal of

Heritage Studies 21 (10): 962-82.

doi:https://doi.org/10.1080/13527258.2015.1040440.

Riegl, Alois. 2006. "The Modern Cult of Monuments: Its Essence and Its

Development." In Historical and Philosophical Issues in the Conservation of

Cultural Heritage (Readings in Conservation), edited by N. S. Price, M. K. Talley, and A. M. Vaccaro, 69-83. Los Angeles: Getty Publications.

Rigney, Ann. 2008. “The Dynamics of Remembrance: Texts Between Monumentality and Morphing." In Cultural Memory Studies: An International and 
Interdisciplinary Handbook, edited by Astrid Erll and Ansgar Nünning, 345-53.

Berlin: Walter de Gruyter.

Robson, Lou. 2019. "Wake Green Prefabs - Conservation Management Plan."

Birmingham City Council.

Ruggles, D. Fairchild, and Helaine Silverman, eds. 2009. Intangible Heritage

Embodied. Dordrecht: Springer.

Silverman, Helaine. 2015. "Heritage and Authenticity.” In The Palgrave Handbook of Contemporary Heritage Research, edited by Emma Waterton and Steve Watson, 69-88. Hampshire: Palgrave Macmillon.

Skrede, Joar, and Herdis Hølleland. 2018. "Uses of Heritage and beyond: Heritage Studies Viewed through the Lens of Critical Discourse Analysis and Critical Realism." Journal of Social Archaeology 18 (1): 77-96. doi:https://doi.org/10.1177/1469605317749290.

Smith, Laurajane. 2006. Uses of Heritage. Oxon: Routledge.

Smith, Laurajane, and Natsuko Akagawa. 2009. "Introduction.” In Intangible Heritage (Key Issues in Cultural Heritage), edited by Laurajane Smith and Natsuko Akagawa. Oxon: Routledge.

Smith, Laurajane, and Gary Campbell. 2017. "The Tautology of 'Intangible Values' and the Misrecognition of Intangible Cultural Heritage.” Heritage \& Society 10 (1): 26-44. doi:https://doi.org/10.1080/2159032X.2017.1423225.

Smith, Laurajane, and Emma Waterton. 2009. “'The Envy of the World?': Intangible Heritage in England." In Intangible Heritage (Key Issues in Cultural Heritage), edited by Laurajane Smith and Natsuko Akagawa, 289-302. Oxon: Routledge.

Stone, Sally. 2019. UnDoing Buildings: Adaptive Reuse and Cultural Memory. London: 
AOM (Author's Original manuscript). This article has been accepted for publication in The International Journal of Heritage Studies, published by Taylor \& Francis. The final revised and published version is available at the following DOI:

https://doi.org/10.1080/13527258.2020.1798271

Routledge.

Tait, Malcolm, and Aidan While. 2009. "Ontology and the Conservation of Built

Heritage." Environment and Planning D: Society and Space 27 (4): 721-37.

doi:https://doi.org/10.1068/d11008.

Taylor, Joel. 2015. "Embodiment Unbound: Moving beyond Divisions in the

Understanding and Practice of Heritage Conservation." Studies in Conservation 60

(1): 65-77. doi:https://doi.org/10.1179/2047058413Y.0000000122.

UNESCO. 2003. Convention for the Safeguarding of the Intangible Cultural Heritage.

Vecco, Marilena. 2010. “A Definition of Cultural Heritage: From the Tangible to the

Intangible." Journal of Cultural Heritage 11 (3): 321-24.

doi:https://doi.org/10.1016/j.culher.2010.01.006.

Wain, Alison. 2014. "Conservation of the Intangible: A Continuing Challenge." AICCM

Bulletin 35 (1): 52-59. doi:https://doi.org/10.1179/bac.2014.35.1.006.

Walter, Nigel. 2014. "From Values to Narrative: A New Foundation for the

Conservation of Historic Buildings.” International Journal of Heritage Studies 20

(6): 634-50. doi:https://doi.org/10.1080/13527258.2013.828649.

Whyte, William. 2006. "How Do Buildings Mean? Some Issues of Interpretation in the History of Architecture." History and Theory 45 (2): 153-77.

doi:https://doi.org/10.1111/j.1468-2303.2006.00355.x.

Witcomb, Andrea, and Kristal Buckley. 2013. "Engaging with the Future of Critical

Heritage Studies: Looking Back in Order to Look Forward.” In International

Journal of Heritage Studies. doi:https://doi.org/10.1080/13527258.2013.818570.

Yarrow, Thomas. 2018. "How Conservation Matters: Ethnographic Explorations of

Historic Building Renovation.” Journal of Material Culture 1 (19). 
AOM (Author's Original manuscript). This article has been accepted for publication in The International Journal of Heritage Studies, published by Taylor \& Francis. The final revised and published version is available at the following DOI:

https://doi.org/10.1080/13527258.2020.1798271

doi:https://doi.org/10.1177/1359183518769111. 